\title{
THE CONTRIBUTION OF THE PRINCIPLES OF THE SOLITARY (MONASTIC) WAY OF LIFE TO ORTHODOX CHRISTIAN SECULAR LIFE ACCORDING TO SEVASTOS KYMINITIS
}

\author{
Anna Karamanidou
}

DOI: 10.17846/CL.2021.14.1.100-112

\begin{abstract}
KARAMANIDOU, Anna. The Contribution of the Principles of the Solitary (Monastic) Way of Life to Orthodox Christian Secular Life According to Sevastos Kyminitis. Sevastos Kyminitis of Trebizond (1632 - 1702) was a distinguished scholar with a comprehensive philological and theological training. In September 1682, Kyminitis succeeded in founding what would later be the renowned Greek Phrontisterion of Trapezous. At the same time, he strengthened the greatest Orthodox Christian mindset. In this context his response to the

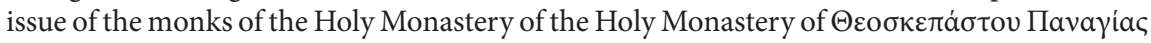
of Trebizond is placed to compose a very important theological work entitled "Exhortation and admonition concerning the monastic way of life" the content of which is also addressed to the "secular state of the Orthodox God". The particular study by the Trebizonian remains unpublished. The manuscript tradition of the "Monastic way of life" is presented in the following codices: Vatopaidi 642, Vatopaidi 686, the Metochion (Dependency) of the MostHoly Tomb 118 and Kos 2. Sevastos Kyminitis followed a tripartite division of the content of his work. In the first part, he analyses the meaning of the term "life of seclusion". In the main part he refers exhaustively to three enemies of the monastic way of life: the flesh, the world, and the Devil, and distinguishes the essential meaning of the senses of sight, hearing, smell, and touch, and the section finishes with the thoughts concerning the Demon and his machinations, in particular, five demonic machinations (schemes).
\end{abstract}

Keywords: Sevastos Kyminitis, the solitary (monastic) way of life, demonic scheme, Basarab Brâncoveanu, Ioannis Karyophyllis, Orthodox Christian secular life, war against the flesh, pedagogy of the senses, sight, hearing, smell, taste, touch

\section{Historical context}

Sevastos Kyminitis of Trebizond (1632 - 1702) was a distinguished scholar of the Post-Byzantine era with a comprehensive philological and theological training (Podskalsky 2005; Karanasios 2001, 250-260; Gritsopoulos 1966; Hurmuzaki 1909, 12-27; Kyriakides 1897; Gedeon 1883, 108-111). His complex, and mainly educational, activity is divided into three periods which are placed respectively in three of the most important spiritual centres of Hellenism at that time: in Constantinople (circa 1650 - 1682), in Trebizond (1682 - 1693), and in Bucharest of the Danubian Principalities $(1693$ - 1702). His orations and didactic presentations in the aforementioned cities are associated with very important events which also made Kyminitis stand out as a spiritual figure of the 17th century.

After a long period of instruction at the Patriarchal School of Constantinople and philosophical and theological training under distinguished teachers such as Ioannis Karyophyllis (Karyes in Thrace, 1589 - Bucharest, 1692) (Karamanidou 2019; Podskalsky 2005, 305-311; Karathanasis 2000, 29-43) and Alexander Mavrokordatos (Constantinople, 1641 - Bucharest, 1709) (Podskalsky 
The Contribution of the Principles of the Solitary (Monastic) Way of Life to Orthodox Christian Secular Life According to Sevastos Kyminitis

2005, 372-375; Stamatiadis 1865, 60-94), he was received in around 1670/71 as the Director of what was called the New Patriarchal School (re-organised as a consequence of the gifts of the great national benefactor Manolakis Kastorianos (Gedeon 1883, 108-111) the teacher of Alexander Mavrokordatos who had been promoted to the Secretary of the then Great Dragoman Panagiotis Nikousios (Karamanidou 2019, 130; Hering 1994, 143-178; Stamatiadis 1865, 29-60).

Upon the unpleasant events which occurred at the Imperial City, Sevastos abandoned the School after more than a decade of teaching and returned to Trebizond, his homeland, in 1681/82, responding affirmatively to a relevant request from his countrymen. The first, and greatest issue which needed to be addressed immediately was the exceptionally low level of the existing Greek and Orthodox Christian education offered in the vast region of Pontus, as an immediate consequence of the harsh Ottoman yoke, which had already been present there for more than two centuries and followed the dissolution of the final free Greek state, the Empire of Trebizond, in 1461, under David the Great Komnenos (Savvidis 2009).

In September 1682, Kyminitis succeeded in founding what would later become the renowned Greek Phrontisterion of Trapezous (Trebizond) with the intention to reduce educational illiteracy and raise the quality of the educational foundations for studies. At the Phrontisterion he gradually developed three levels of studies and transferred the teaching of lessons of the Patriarchal School of Constantinople there. His contribution to the elevation of the spiritual level of Pontic Hellenism by his teaching the works of Ancient Greek literature was fundamental. At the same time, he strengthened the greatest Orthodox Christian mindset and the national identity of the whole body (pleroma) of the Church with his instruction focused on the works of the Holy Fathers, preserving, in consequence, the Orthodox Christian tradition in theory and practice.

His response to the request of the monks of the Holy Monastery of Panagia Theoskepastos of Trebizond to compose, what would become a very important theological work, "Exhortation

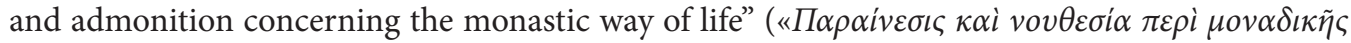

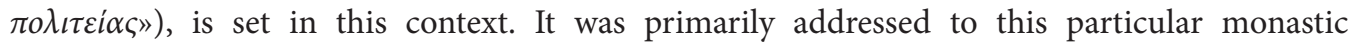
brotherhood, without excluding, however, the broader community of Orthodox believers living in the world, since "the greatest things come together more commonly when treated also in the worldly way of life of the Orthodox people which is according to God" (Kos 2, f. 397r). In other words, the title confirms that the life in Christ of the Orthodox Christians is one and common for the totality of the body of the Church without essential distinctions and divisions amongst the faithful wherein they can freely choose to live either according to the world, or according to the monastic life with a common purpose "because all of us alike are obliged, both monastics and laypeople, to be pleasing to God in the present life so that we might inherit the future heavenly kingdom" (Kos 2, f. 398 ${ }^{\mathrm{r}}$.

Sevastos's work regained its importance during the third period of his life in Bucharest (1693 1702). The capital city of the Danubian Principalities had developed into a famous cultural capital during the second half of the 17th century; with the unique confluence of the Hellenic constituents, princes, merchants and scholars, in a manner which sparked a Neo-Hellenic Renaissance with Bucharest as its centre. Prince Constantin Basarab Brâncoveanu of Wallachia (1688 - 1714) (Karamanidou [IOTA] 2019; Glykofrydi-Leontsini 2007, 379-392; Karathanasis 2000, 69-81; Jorga 1971, 189-199) who dedicated much care to the spiritual upbringing of his people and to the prosperity of his country, played a great role in the period. The arrival of Kyminitos in Bucharest sufficiently supports the fact that he was associated with the foundation of the first Greek school, the eponymous Hellenic Academy, in a fruitful collaboration with Patriarch Dositheos Notaras of Jerusalem (1669 - 1707) (Dură 1977; Turndeanu 1985; Klaus-Peter Todt 2002) who resided there and who spiritually guided the Hellenic cultural movement primarily in Bucharest. Sevastos's fame, his knowledge and pedagogical charisma brought about his undisputed placement as the 
Director of the Academy and as a teacher of the third and higher levels of philosophy at the school, according to the model of the Patriarchal Academy of Constantinople. The position of the Trebizonian scholar in the spiritual and educational leadership of Bucharest was overlooked until his own death in the year $1702^{1}$.

It is clear and confirmed by various sources that the connection between Kyminitos and the enlightened reformer Prince Brâncoveanu was very close. First of all, the prince had personally charged him with the education of his children. Secondly, Basarab himself received the title

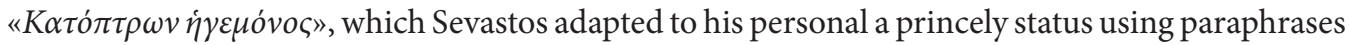
of well-known texts from Ancient Greek and Byzantine literature and dedicated them to him (Karamanidou [IOTA] 2019). These texts included the «E $E \dot{\eta} \gamma \eta \sigma \eta »$ on Aristotle's work “On Virtues" (Kos 2, ff. 326 $6^{\mathrm{r}}-353^{\mathrm{r}}$ ), the translation of the work "On Kingship" by Bishop Synesios of Cyrene for the Emperor Arcadius (Kos 2, ff. $144^{\mathrm{r}}-145^{\mathrm{v}}, 192^{\mathrm{r}}-201^{\mathrm{v}}$ and $206^{\mathrm{r}}-250^{\mathrm{r}}$ ), and the translation of the work "Royal Education" by Theophylact of Ochrid to the Emperor Constantinos Doukas Porphyrogennitos (Kos 2, ff. $251^{\mathrm{r}}-304^{\mathrm{r}}$ ). He also composed a series of encomiastic orations and epigrams for the prince (Kos 2, ff. 369v-396 $)$ who, it is worth noting, suffered a martyric end along with his four children on the 15th of August 1714 in Constantinople, beheaded by the Turks. He was included in the class of Neomartyrs of the Orthodox Church by the Church of Romania. The memory of the holy neomartyr Constantin Brâncoveanu and of those with him is honored on 21 March and on 16 August.

With its diverse moral tenets, Kyminitis's work from Trebizond "On the solitary (monastic) way of life" is not only addressed to monks and nuns, but to all faithful Christians who pursue "the orthodox way of life according to God." He restored this work to relevance and published it in Bucharest "in the year of the Saviour, 1699" (Kos 2, f. 397). Indeed, at the conclusion of what is likely a text by Sevastos's own hand in Codex 2 from the island of Kos it is that 30 September 1699 is a precise date of completion and the place of composition is the Monastery of St Savas in Bucharest, which is a dependency of the "Holy and Lifegiving Sepulchre" of the Patriarchate of Jerusalem $\left(\operatorname{Kos} 2, \mathrm{f} .430^{\mathrm{r}}\right)$. The reference to the particular monastery clearly specifies Kyminitos's place of residence during the time of his presence and activity in the Danubian Principalities, and the place where the Academy of Bucharest, called Princely or Authoritative (Academia Domnească de la Buciureşti) (Papaioannou 2004) was housed, and for this reason it is remembered as the "Academy of St Savas" which ceased to exist in 1821 by decision of the Turks (Katathanasis 2000,

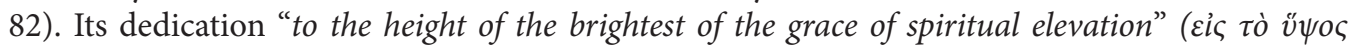

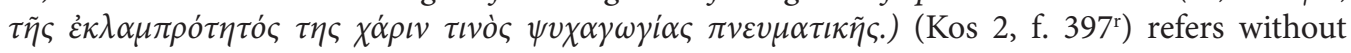
the slightest doubt to Prince Constantin Brâncoveanu. Spiritual cultivation as a major goal of the writer is fully confirmed by its content and the topics which guide the life of each faithful Orthodox Christian towards the pure and virtuous life in Christ. Of course, there are points which are clearly revisions of the original work, with the exhortations being adapted to specific personal responsibilities of an Orthodox Christian prince, and in this manner are matched with exemplary

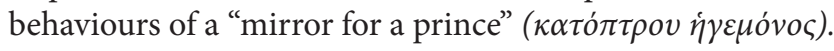

The particular study by the Trebizonian remains unpublished. However, the fact that it has hitherto been transmitted in four known manuscripts, leads us to suppose that it was the work of

His disciple John Comnenos wrote about Sevastos in the following epitaph inscription: "Here lies the wise presbyter of great repute called Sevastos of the house of Kyminitis; father of the illustrious city of Trebizond. To his many students who are most grateful, he bestowed words of education, and to their deceased teacher they offer libations of tears. The great torch of philosophers has been quenched in their midst. And so beseech Christ to grant unto him his inheritance from above, an honour for his labours. On a Sunday in the year 1702." 
The Contribution of the Principles of the Solitary (Monastic) Way of Life to Orthodox Christian Secular Life According to Sevastos Kyminitis

an exceedingly important advancement and resonance. The manuscript tradition of the "Solitary way of life" is presented in the following codices:

- Vatopaidi 642: [paper codex from the 18th century, 153 numbered pages (19X14), ff. $10^{\mathrm{r}}-35^{\mathrm{r}}$ ];

- Vatopaidi 686: [paper codex from the 18th century (1724), 146 numbered pages (21X25), ff. $\left.107^{\mathrm{v}}-146^{\mathrm{v}}\right]^{\mathrm{j}}$;

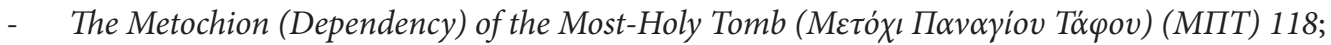

- Kos 2: [paper codex from the late 17th - early 18th centuries, 482 numbered manuscript folia (250X160), ff.397r-430r] (Kos 2, ff.397 $\left.{ }^{\mathrm{r}}-430^{\mathrm{r}}\right)^{2}$.

Before we proceed to the theological approach of the content of Sevastos's work, we deem it necessary to mention the monastic brotherhood which, by its request, invited the author of this significant work which belongs to the genre of moral instruction manuals for Orthodox Christian monastic and secular ways of life. So, the topic of his work is certainly not unprecedented. From the introduction of the first forms of ascetical and monastic ways of living in the 4th century, the Fathers and ecclesiastical writers had been engaged in composition of rules which dealt with problems that arose from the opponents of monasticism and from heretical offshoots, lauded the life of virginity, and also called attention to the great diversity of the devil's traps.

Indicative of these early works are the following:

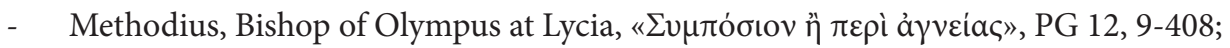

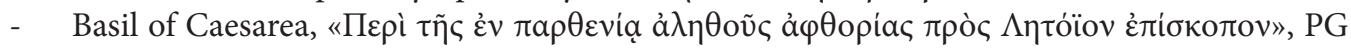
30, 669-809;

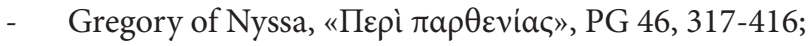

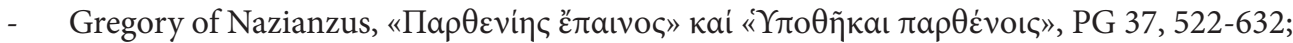

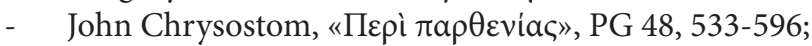

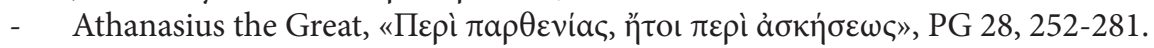

There are certainly other less expansive works and a number of references by later Fathers and ecclesiastical writers which are included in the whole of ascetic and monastic literature.

The long-standing conclusive result of the matter of the overview of the topic in the Orthodox Church can be summarized in the following way:

Through their writings, ecclesiastical writers, who were themselves convinced of the superiority of virginity over marriage, engaged in a kind of propaganda in support of virginity as well as critique of the positions of the enemies of the life of virginity. However, the most essential aspect of what they presented is that they maintained the ascetic life within the established context of the divine liturgy by shining light upon the place of both manners of life in God's plan for mankind (Zisis 1997, 256).

The same spirit dominates in Kymnites's work as he constantly supports his arguments by many

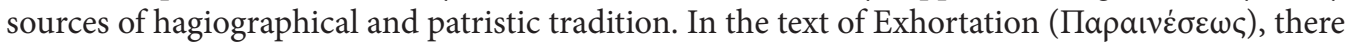
are 83 patristic references (to Basil the Great, Gregory the Theologian, John Climacus, Ephraim

2 Based on the codices mentioned above we are preparing the critical edition of "The Solitary Way of Life" with a full commentary on the historical information about its author and with a theological analysis of its content. The present talk is a prelude to the planned critical edition and is firstly based upon the text of the unpublished Codex 2 of Kos. 
the Syrian). The recipient of the first work was a monastic sisterhood in the historical monastery of Panagia Theoskeptastos, located on the slopes of Mount Mithrios between a lake and the acropolis of Trebizond (Kizlar Monastery, in the region of Boztepe). It encompasses a cave church, cells, smaller churches and places of burial. Its foundation is attributed to Emperor Alexios III the Great (Komnenos) (1349 - 1390), his wife Theodora Kantakouzene, and his mother Irene Palaiologina, whose dedicatory inscription has been preserved. The tombs of the emperors Andronicus, Manuel III and Alexios IV, the sons of Alexios III, can be found in the monastic complex.

The monastery was founded in 1340, initially as a women's monastery, restored by Alexios the Great (Komnenos) IV (1417 - 1429). The monastery was devastated during the Ottoman conquest and plundered. In the year 1843 it was restored again by Patriarch Germanos IV (first patriarchal term: $1842-1845$, second patriarchal term: 1852 - 1853) and run by a monastic sisterhood until the Asia Minor Disaster of 1922. A new disaster ensued and it was transformed into stables for animals until it was restored in 2015 by the efforts of the Ecumenical Patriarch Bartholomew and returned to partial liturgical use, constituting a historical monument of Trebizond. ${ }^{3}$

\section{Theological analysis}

\section{The monastic way of life. Meaning and purpose}

In the opening quotation, it is determined that a common purpose "of all Orthodox Christians" is the inheritance of the future heavenly kingdom of God through the fulfilment of His commandments in the present life.

However, the distinctions in motivation for the attainment of salvation divide the saved into three classes: the sons and heirs of the kingdom, with their motivation being love for God; the wage labourers who are rewarded as doers of the commandments; and the slaves who respond to the divine calling "through the fear of damnation".

The solitary way of life is the choice of the monastic and ascetic way of life which conforms to the class of sons and heirs to the kingdom of God, with the attempt at a complete adaptation of the evangelical principles, the precise observance of the commandments of God, the imitation of angelic conduct and dominance over the passions. As a "soldier" and as an "athlete" of Christ, the monk has to deal with three opponents: the flesh, the world, and the Devil.

\section{The three enemies of the monastic way of life}

\section{a. The war against the flesh}

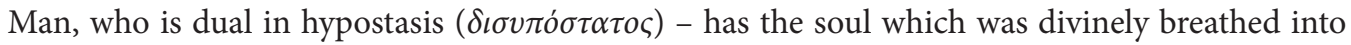
him and flesh which is earthly, material, mutable, corruptible, and which "desires the things of the world and its pleasures" 4 . In other words, the mindset of the flesh is in opposition to the mindset of the soul and wages a spiritual war. The domination of a healthy mindset requires three

3 The Holy Monastery of Panagia Theoskepastos and the aforementioned Holy Church of Panagia Chrysokephalos of Trebizond, together with the noted imperial figures in $397^{\mathrm{r}}-397^{\mathrm{v}}$, would constitute an object of special study concerning the historical notes of codex 2 of Kos.

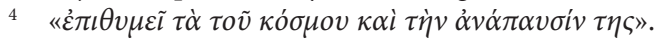


The Contribution of the Principles of the Solitary (Monastic) Way of Life to Orthodox Christian Secular Life According to Sevastos Kyminitis

preconditions: the application of the divine commandments by the grace of God, constant vigilance, and the utilisation of forces which defeat any fleshly desire. In particular, Sevastos emphasises the therapeutic activity of the opposites, according to medical practice, and underscores, by other examples, the necessity of attention to every detail of the spiritual struggle "that we might not give a single cause to the enemy to enter and dominate our thoughts, and subject us to his will, and make us slaves and captives to his obedience, and kill us and punish us with eternal damnation by his word" (Kos 2, ff. 400v-401 $)$.

\section{b. The war against the world}

With the same spiritual weapons and with God's help, the faithful Christian can also deal with the matters of the world which wage war against his divine purpose. But because the human senses play the role of intermediary ports of entry into the soul for the world, Sevastos considers it appropriate at this point to introduce the teaching "On the pedagogy of the senses" $\pi \alpha \iota \delta \alpha \gamma \omega \gamma i \alpha \varsigma \tau \tilde{\omega} v \alpha i \sigma \theta \dot{\eta} \sigma \varepsilon \omega v)$ to examine the dangers posed by the five senses (i.e. sight, hearing, smell, taste and touch).

\section{i. Concerning sight}

The first approach of the sense of sight concerns the faces of our fellow human beings. The real meaning is found in the internal beauty of the soul and intelligence, which makes men virtuous servants of God "and therefore we must love them according to God" regardless of their external beauty $\left(\operatorname{Kos} 2, \mathrm{f} .401^{\mathrm{v}}\right)$. The second approach concerns the things regarded as good by the world, such as: wealth, honours, and pleasures, which the faithful, and certainly monks who have rejected "the world and the things thereof" must not be enslaved to since those things are "fleeting, vain, and corrupt" (Kos 2, f. 402 $2^{\mathrm{r}}$. This particular note addressed to those who live the monastic life, the recipients of his oration, is bolstered by Sevastos with the example of worldly merchants who display zeal and put themselves in danger "night and day" for ephemeral worldly riches and neglect the inheritance of God's eternal kingdom.

The third approach concerns the notion of the immeasurable size of the universe and its ceaseless movement in accordance with the governing providence of God. God the creator "fashioned the world itself for our sake and for our own needs and salvation, and again he fashioned through His word and so that we might enjoy His heavenly kingdom" (Kos 2, f. 402 ). This world is "a gymnasium, a wrestling ring, and a stadium" for men to compete with good intention and "with the help of God, the Saints, and the Angels" (Kos 2, f. 402 $-403^{\mathrm{r}}$ ).

5 The safeguarding of the five senses is explained by St Nikodemos the Athonite (18th century) in his book, Advisory Manual in "Chapter 3: On the Safeguarding of thw Sense of Sight (Nicodemos, the Athonite 1801, 48-58). Chapter 4: On the Safeguarding of the Sense of Hearing (Nicodemos, the Athonite 1801, 63-68). Chapter 5: On the Safeguarding of the Sense of Smell (Nicodemos, the Athonite 1801, 69-72). Chapter 6: On the Safeguarding of the Sense of Taste or the Mouth (Nikodemos, the Athonite 1801, 7686) and Chapter 7: On the Safeguarding of the Sense of Touch" (Nikodemos, the Athonite 1801, 96-101). 


\section{ii. Concerning hearing}

The most extensive analysis concerning the sense of hearing concentrates on the praise of men for their virtuous actions. The first potent antidote is found in the examination of personal and secret wicked thoughts of the heart, carnal passions and evil will. Cruelty, faithlessness, and doubt, pharisaical high-mindedness, and the judgment of one's neighbour, are listed with examples to demonstrate that "only one thing is able to erase all of the other accomplishments and virtues of ascesis" (Kos 2, f. 403 ${ }^{v}$ ). The second antidote is found in one's personal unworthiness, even in an unlikely circumstance when someone accomplishes all divine commandments with precision, because the only completely sinless one is our Lord Jesus Christ.

The teaching on hearing extends to abusive words against the believers whether they are true, because they are concerned with examining real wrongdoings, or they are calumnies and lies originating from a bad disposition or from insufficient information about their fellow men. In the first case, those who judge are seen as "spiritual and true physicians" (Kos 2, f. 406") because in this manner they lead to repentance "from evil which accuses them" and to the achievement of "laudable virtue and salvation" (Kos 2, f. 407 ). In the second case of unjust calumny, the first thought relates to Jesus Christ who was sinless and slandered until His death "through love and the imitation of the Master and of the Saints of old" (Kos 2, f. 406 v). Following this, the sense that God allows such unjust situations is emphasised because "without any effort, only with chagrin and sorrow of heart does He cure and heal the hidden and imperceptible and infinite failures of our souls" (Kos 2, f. 407').

\section{iii. Concerning smell}

In his teaching concerning the sense of smell, Sevastos defines it as bodily and spiritual. In the bodily sense of smell, he suggests the avoidance of "effeminate, indecent, licentious and soulharming smells" which cloud the nous and the piety of the soul. The positive approach concerns "the ecclesiastical and spiritual incense which elevates the nous to a spiritual and heavenly fragrance" (Kos 2, f. 410 ), which the synaxarist (hagiological) explanations of the experienced Saints of the Church recorded in the synaxarist (hagiological) accounts as the "ever-delightful flowers of paradise" (Kos 2, f. 410 ).

The spiritual fragrance, according to the erudite Kyminitis, lies in wait for the faithful in the teachings and understanding of the mysteries, in the knowledge and learning "of the divine judgments and commandments" (Kos 2, f. 410v); such undertakings breathed the breath of true life, the fragrance of Christ, into human communities. On the contrary, the idolatrous life which is removed from God breathes an odour of death twofold, that of the inevitable bodily death and of the looming spiritual death of eternal damnation.

\section{iv. Concerning taste}

Sevastos does not make a particular reference to the sense of taste. He devotes only three lines to it, mentioning that everything that has been written "Concerning the flesh, concerning the first enemy" applies to it as well. But what connection does the flesh have with the sense of taste? When the flesh wants to overeat, the sense of taste can conquer it with embracing hunger or thirst, or when the flesh seeks good and delicious food, the sense of taste can conquer this desire with bland food or food fit for ascetics, by eating only dry food and by drinking water, "that we might not give 
The Contribution of the Principles of the Solitary (Monastic) Way of Life to Orthodox Christian Secular Life According to Sevastos Kyminitis

a single cause to the enemy to enter and dominate our thoughts, and subject us to his will, and make us slaves and captives to his obedience, [...]" (Kos 2, ff. 400 $\left.{ }^{\mathrm{v}}-401^{\mathrm{r}}\right)$.

\section{v. Concerning touch}

The sense of touch is described as the most dangerous "because of the unsteadiness of our nature and because of the innate propensity and inclination towards the carnal passions" (Kos 2, f. 411 ). On this topic, Sevastos becomes especially analytical, and he recommends to the monks and nuns the utmost attention to the contact of the members of their bodies with other people. The pitfalls and perdition, even of ascetics, "for their inattention" makes the provocation of carnal scandalization the most dangerous of all. He invokes the patristic witness of Basil the Great and of Gregory the Theologian who emphasized the necessity of great attention and of non-acceptance, and also of not provoking the demon of sexual sin. Worldly cares are considered unacceptable for eroding the monastic life for they provoke "a myriad of evils in the monasteries and coenobia, both to coenobites and monks" alienating them "from ascesis and from spiritual progress" (Kos 2, f. 413").

\section{c. The war against the devil}

The ancestral sin, on the one hand, voluntarily alienates the human race from God, and on the other, grants great authority to the Devil over men who powerlessly submit themselves to idolatry, demonolatry, human sacrifice, and every sort of passion. Certainly, the necessary foreknowledge of God never forsook humanity, but saved it from complete destruction, as there have always been "righteous people, prophets and patriarchs", "magnanimous and brave" people, who resisted the wicked will and the general dominion of evil.

The Lord Who became man completely reversed the grim situation as "he deposed the tyrant and redeemed the world from corruption" (Kos $\left.2, \mathrm{f} .414^{\mathrm{v}}\right)$. The authority of the Devil was destroyed, yet "through the effort of men", so that their good or evil intentions might be revealed, God allowed the assault of wicked thoughts which only with human consent is able to predominate. The cunning devil manipulated this potential and assaulted men with different tactics, attempting to "sever him from the goodness and good pleasure of God and to make him an enemy of God by transgression and rebellion" (Kos 2, f. 415 ).

The revelation of the hostile schemes is necessary for the spiritual struggle of the believers. This is why the Trebizonian scholar recommends studying the writings of the ascetic and neptic fathers and in particular the writings of John Climacus and John of Sinai. For the aid "of the audience and the readers" (Kos 2, f. $415^{\mathrm{v}}$ ), he continues in the exposure of five "schemes of the enemy" and the manner of dealing with them.

\section{i. The first demonic scheme}

In the course of his life, each man finds himself constantly before the crossroads of virtue and evil. Besides their essential distinction in regards to their content, these two paths have diametrically opposite qualities, both in their beginning and their end. In other words, while virtue in the beginning "seems bitter, laborious, and painful", in the end it is "the sweetest and most pleasant" end results in the heavenly kingdom; but sin, on the contrary, in the beginning seems "tasty and sweet" but in the end winds up being bitter, death-bringing, and equal to the "unceasing hellfire" $\left(\right.$ Kos 2, f. $\left.415^{\mathrm{v}}-416^{\mathrm{r}}\right)$. 
The sensible and prudent, however, by the correct judgment of their nous, do not fall for the wicked schemes of the devil and foresee the end of both paths, so as to make the correct choice which, with "pain and effort of the virtues", leads most certainly to the "infinite gain" of the kingdom of heaven (Kos 2, f. $416^{\mathrm{v}}$ ).

\section{ii. The second demonic scheme}

To the acceptable philosophical notion of the tripartite division of the soul, to reason, spirit, and appetite, Sevastos emphasises the dominant role of reason over the other two powers. The purpose of God the Creator's endowment of the soul with these powers is for the discerning rational nous to use them appropriately in order to defeat "the three enemies: the flesh, the world, and the Devil" and to desire the acquisition of the good works and virtues of the kingdom of heaven (Kos 2, f. $\left.417^{\mathrm{r}}-417^{\mathrm{v}}\right)$.

The devil knows this spiritual function well, and because of this he places the domination over the rational nature of the soul as his primary and overarching goal. His deceptive scheme leads to an apparent inaction in regards to the two other powers of the soul. He lies in ambush for the opportunities to draw near to the nous in order to pervert and to transform "the judgment of reason" to evil (Kos 2 , f. $\left.417^{\mathrm{v}}\right)$.

However, the wise and careful believers are vigilant in their spiritual struggle and do not allow any demonic attack against their sovereign rational nous, orientated unwaveringly towards the kingdom of God "and through this accurately observe the life-giving commandments of the Gospel" (Kos 2, f. $\left.419^{\mathrm{r}}-419^{\mathrm{v}}\right)$.

\section{iii. The third demonic scheme}

Most extensive is Kymnitos's analysis on the third demonic scheme, which is aimed at the obsolescence of the virtuous way of life of the believers and, of course, he makes use of many references to the biblical and patristic traditions.

Virtue and sin are two opposing poles of human existence, and their difference initially appears to be easily distinguishable. The snare of the devil is planted for those who effectively struggle in the spiritual contest of virtue and now harvest its first fruits. The evil one "leaves the ascetic in his comfort and does not bother him" (Kos 2, f. 419v) while he simultaneously engages in a systematic and concerted praise of all the achievements of his virtuous life. The snare lies hidden in the fall of the ascetic to the two deadly evils of pride and of the judgment of one's brother. With this double fall, the first two commandments of God, which refer to the love for God and one's neighbour, are transgressed. And this is because egoistic pride poisons every virtuous achievement while judgment annuls every loving approach towards one's fellow man.

The knowledge that there is not "a single human being on the earth, [who is] as much of a sinner as he is, that does not have some kindness in his reason". The only one who is absolutely full of evil is the devil and the demons who follow him. Moreover, there is not a single righteous person "who is completely pure of filth", for even one day, except our sinless Lord Jesus Christ.

Sevastos underscores the complexity and the multitude of demonic schemes, whose confrontation and avoidance he considers to be impossible for the faithful, "if they do not have the assistance, protection, grace, and power of God" (Kos 2, f. 425r). For this reason, vigilant prayer and the fear of God are necessary, lest the struggling believer is deprived of the protection of divine grace by some failure to act in a manner which is pleasing to. 
The Contribution of the Principles of the Solitary (Monastic) Way of Life to Orthodox Christian Secular Life According to Sevastos Kyminitis

\section{iv. The fourth demonic scheme}

The juxtaposition of bodily and spiritual health gives Kyminitis the opportunity, on the one hand, to approach the meaning and the interplay between the two components of the dipartite man, those of the body and of the soul, in an Orthodox manner, and on the other hand, to reveal a new demonic scheme.

Bodily health is indicated by the good order of its members throughout the person's limited life on earth. "The soul is healthy whenever its parts (reason, spirit, and appetite) maintain their order and are in peace amongst themselves" (Kos 2, f. 425 v). Every disturbance of their balances causes the corresponding illness, although while the bodily illness is immediately felt through pain and requires medical treatment, the illness of the soul is not immediately perceived and its treatment is delayed.

\section{v. The fifth demonic scheme}

The analysis of the fifth scheme of the devil concerns the most sensitive topic of the internal divisions and contentions which appear in the monastic communities, but also in the habitations of men in general.

The evil which the evil one incites appears when false brothers, either monks, or laymen, as "servants of Satan" propagate "bad, bitter, and poisonous words, and slander, debilitation, and contempt" against their brothers (Kos 2, ff. $428^{\mathrm{v}}$ ). The demonic scheme extends to the wounded monks, as "great affliction and pain occur in their hearts and inflame their anger [...], and stimulate them towards defensiveness and retribution against their enemies" (Kos 2, ff. $428^{\mathrm{v}}-429^{\mathrm{r}}$ ). As a result of all of these displeasing conditions, quarrels, animosity, and even violence is created between brothers. The scandal of a monastic brotherhood is complete when on one side insults, slanders, and scorn predominate, and on the other, the spirit of retaliation and punishment of the wronged prevails.

Sevastos emphasizes that this whole demonic scheme can be overturned by the illumined judiciousness of the nous of the sensible things and can open "a hidden and unknown layer and method of spiritual salvation" (Kos 2, f. $428^{\mathrm{r}}$ ).

The audience of the oration includes everyone, "both hermits and coenobites, lay people, both men and women, Orthodox people of all ages and every race" (Kos 2, f. 429v), thus so that with consistency in every spiritual struggle in the present life they might achieve salvation.

He reminds the reader of the three enemies of spiritual salvation, the carnal mindset and will, the worldly mindset and will, and the satanic mindset and will, which produce eternal spiritual death and unceasing hellfire for the man who is dual in hypostasis. The precise observation of the divine commandments necessarily requires "the grace, assistance, and perception of God concerning our tutelage" (Kos 2, f. 430 r), which has the incarnate Son of God as its primary expression. The Exhortation is concluded by the common patristic Trinitarian invocation in the form of the liturgical prayers.

\section{Epilogue}

The most fundamental contribution of the Byzantine and Post-Byzantine ecclesiastical body of literature to the European framework of values is that it negates the abstract and theoretical underpinnings of moral values and displays the virtues by the timeless exemplar of the God-man Jesus Christ. The Orthodox neptic teaching and ascetic life of all believers is invariably based on 
the threefold goal of: purification from the passions, divine illumination, and theosis. Sevastos Kymnitis of Trebizond is an authentic transmitter of this tradition.

\section{REFERENCES}

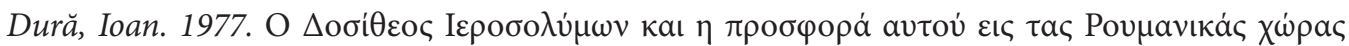

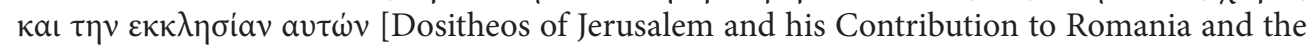
Romanian Church]. Athens.

Emil Turdeanu. 1985 Études de literature roumaine et d' écrits slaves et grecs des principautés roumaines. Leiden.

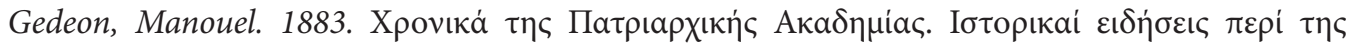

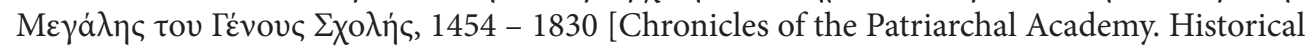
Editions of the Great School, 1454 - 1830]. Constantinople.

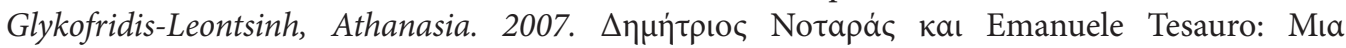

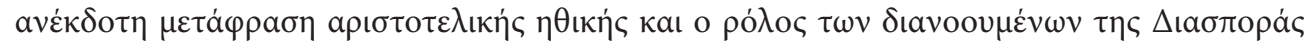

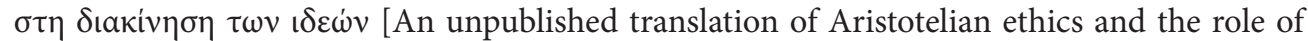

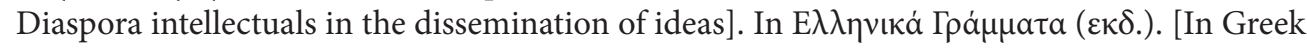

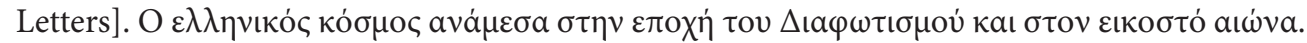

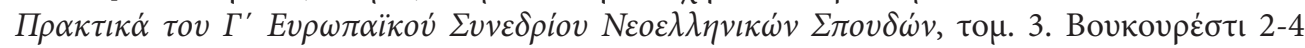
Iovviou 2006 [The Greek world from the Age the Enlightenment to the Twentieth Century. Proceedings of the Third European Conference on Modern Greek Studies, vol. 3. Bucharest 2-4 June 2006]. Athens, 379-392. http://www.eenscongress.eu).

Gregory Sinaitis. 2005. Грฤүó On the Four Hierarchs]. In Rigo, Antonio (ed.). Il monaco, la Chiesa e la Liturgia. La mistica Cristiana tra Oriente e Occidente 4. Firenze, section 3, 7, 9.

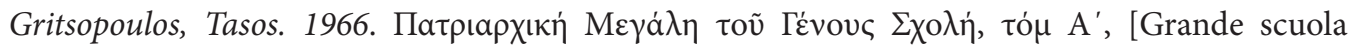
patriarcale del genere, vol I]. Athens.

Hering, Gunnag. 1994. Panagiotis Nikousios als Dragoman der Kaiserl. Gesandtschaft in K/onpel. In Jahrbuch der Österreichischen Byzantinistik 44, 143-178.

Hurmuzaki, Eudoxiu 1909. Documente privitoare la Istoria Românilor culese de E. de Hurmuzaki. Texte Greceşti, privitoare la Istoria Românească culese şi publicate cu introducere şi indicele numelor de A. Papadopulos - Kerameus, vol. 13. Bukarest.

Ionescu Ştefan - Panait I. Panait. 2014. Constantin Vodă Brâncoveanu - Viața - Domnia - Epoca. Bucureşti.

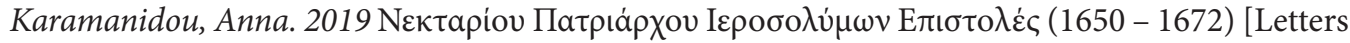
of Patriarch Nektarios of Jerusalem $(1650$ - 1672)]. Thessaloniki.

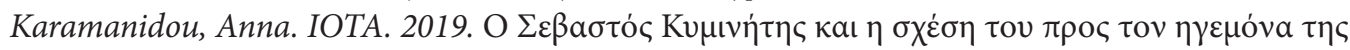

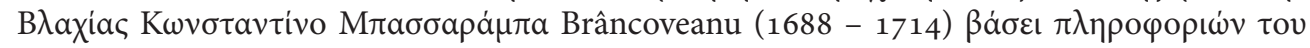

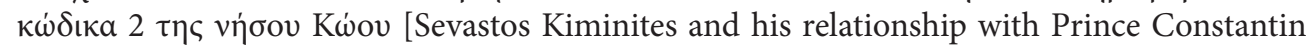
Basaraba Brâncoveanu (1688 - 1714), based on codex 2 from the island of Kos]. In International Orthodox Theological Association: Pan-Orthodox Unity and Conciliarity. 9-12 January 2019. Iasi, Romania.

Karanasios, Chariton. 2001. Sebastos Trapezuntios Kyminetes (1632 - 1702). In Serta Graeca. Beiträge zur Erforschung griechischer Texte. Band 10. Wiesbaden.

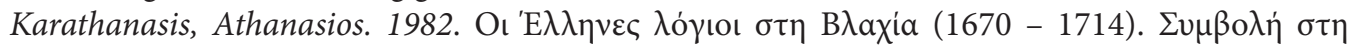

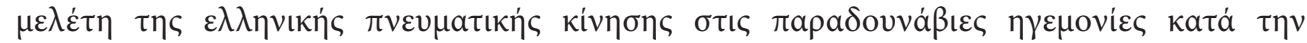

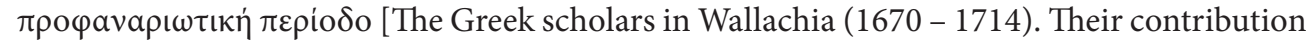


The Contribution of the Principles of the Solitary (Monastic) Way of Life to Orthodox Christian Secular Life According to Sevastos Kyminitis

to the study of the Greek spiritual movement in the Danubian Principalities during the Pre-

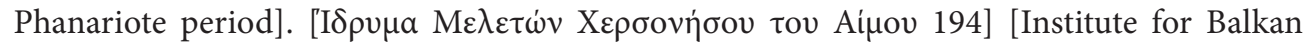
Studies 194]. Thessaloniki.

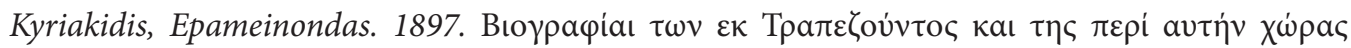

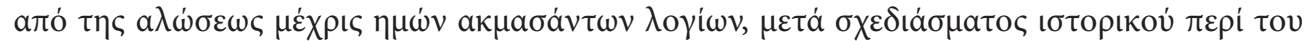

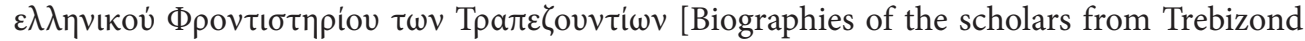
and of the country itself from the Fall of Constantinople until the Greek Revolution, and the history of the Greek Phrontisterion of Trapezous]. Athens.

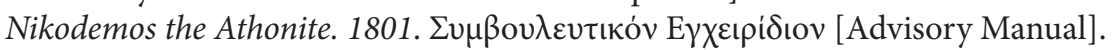

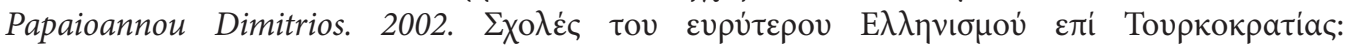

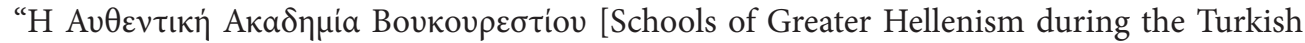

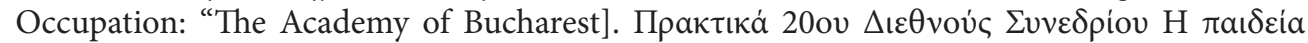

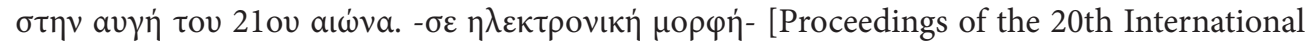
Conference Education at the dawn of the 21st century. - in electronic form]. Patra. http:// www.eriande.elemedu.upatras.gr/eriande/synedria/synedrio2/ praktika/papaioannou.htm).

Papatriantafyllou-Theodoridis, Niki. 1980. H $\Sigma \chi 0 \lambda \eta \dot{~ \tau o v ~ M a v o \lambda a ́ k \eta ~ K a \sigma \tau o p ı a v o u ́ ~ \sigma \tau \eta v ~}$

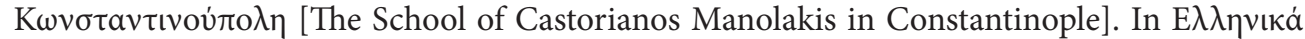
[Hellenica] 32, 360-364.

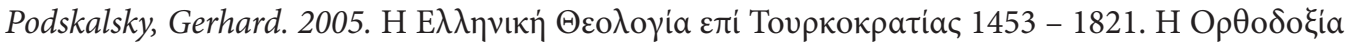

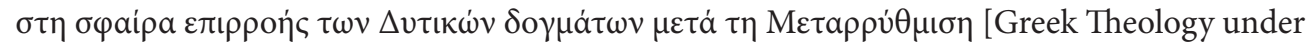
Turkish Occupation 1453 - 1821. Orthodoxy in the sphere of Western doctrine after the Reformation]. Athens.

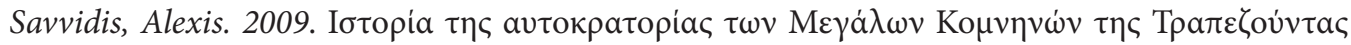
(1204 - 1461) [A History of the Great Komnenian Empire of Trabizond (1204 - 1461)]. Thessaloniki.

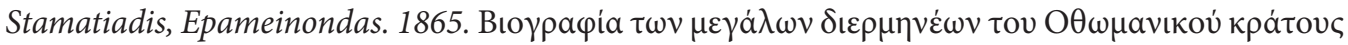
[A Biography of the great interpreters of the Ottoman state]. Athens.

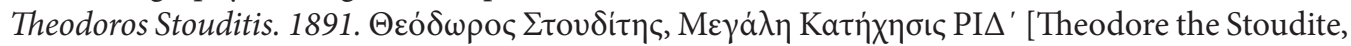
Great Catechesis CXIV]. In Auvray, Emmanouel (ed.). Sancti Patris Nostri et Confessoris Theodori Studitis Praepositi Parva Catechesis. Paris, 28-35.

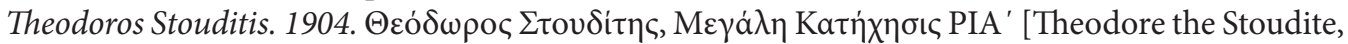
Great Catechesis CXI]. In Papadopoulos-Kerameus, Athanasios (ed.). Theodoros Studites,

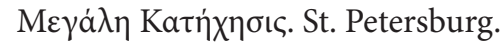

Todt, Klaus-Peter. 2002. Dositheos II. Von Jerusalem. In Corpus Christianourm - Turnhout, Brepols - publishers (ed.). La Théologie byzantine et sa tradition II (XIII ${ }^{e}$-XIX ${ }^{e}$ s.). Belgium, 659-711.

Tsourkas, Cleovoulos. 1970. Germanos Locros, archevèque de Nysse et son temps (1645 - 1700)

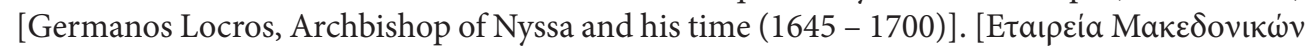

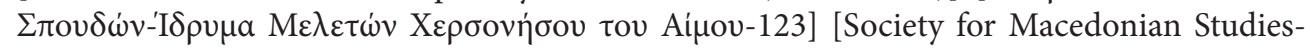
Institute for Balkan Studies-123]. Thessaloniki.

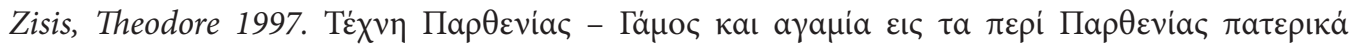
$\varepsilon$ s ya [The Art of Virginity - Marriage and Celibacy in the Patristic Works on Virginity].

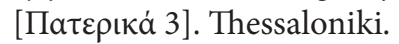


assoc. prof. Anna Karamanidou ThDr.

Aristotle University of Thessaloniki

Faculty of Theology

Faculty of Theology - School of Pastoral and Social Theology

Department of Holy Scripture and Patristics

University Campus

54124 Thessaloniki

Greece

annakarm@past.auth.gr 